\author{
Alberto Toutin \\ Profesor Facultad de Teología \\ Pontificia Universidad Católica de Chile
}

\title{
El "Dios" huidizo de los escritores
}

A los alumnos del curso "A la búsqueda del Dios perdido", 2007.

“Te perdí como a una melodía. Como a una virgen enamorada te dejé ir. ¿Podré olvidar mi olvido?"

Arturo Fontaine, Tu nombre en vano (1).

Este poema del escritor chileno Arturo Fontaine (1952) expresa pudorosa y claramente una cierta constante en la manera como muchos escritores contemporáneos se refieren a la realidad que llaman "Dios". Primero existe la percepción de que el "Dios" al que se refieren, apenas se lo puede nombrar o permanece como un sujeto velado, implícito, y que, a lo más, puede ser designado, invocado y muchas veces interpelado como un tú. Luego, el "Dios" del que hablan o callan es de una consistencia frágil, vulnerable, como un cristal que se puede romper o como una joya pequeña que se puede perder. "Dios" no es una realidad del orden de las certezas inconmovibles y confortablemente adquiridas, de una vez para siempre, sino más bien del orden de lo huidizo, de lo que, en algún momento, está presente y que luego se ausenta, que se manifiesta y se oculta. Aun más, "Dios" es para Fontaine, como para muchos escritores, aquello que se puede perder u olvidar. Pero es precisamente la memoria de este olvido la que, de manera paradójica, se constituye en el último vestigio de una presencia ahora ausente. La memoria de este olvido se transforma entonces, en la creación literaria de Fontaine, en una suerte de nostalgia de Dios... que lo pone en búsqueda no solo del Dios que alguna vez conoció, sino del que ahora se hace presente de manera enigmática en un Tú como "esa pregunta sin fondo (2)" o en ese "Dios escondido" o en un olvido que se vuelve pregunta heurística con la que se lo busca en los meandros de la memoria, en la opacidad del presente: “¿Podré olvidar mi olvido?”.

(1) Arturo Fontaine, "Poema X", Tu nombre en vano. Santiago: Editorial Universitaria, 1995, p. 22.

(2) Arturo Fontaine, "Poema XII", Tu nombre en vano. Santiago: Editorial Universitaria, 1995, p. 24. 
En el marco de nuestro seminario interno de profesores de la Facultad de Teología de la Pontificia Universidad Católica de Chile, hemos estado reflexionando en las ponencias anteriores sobre la pregunta acerca de la posibilidad de afirmaciones de carácter absoluto en una cultura pluralista. De este camino, hemos ido perfilando, dos dimensiones que se encuentran implicadas en esta problemática: La realidad de Dios, revelado en Jesús que se comunica de un modo eminentemente relacional e histórico, como dos rasgos que definen su ser mismo de cara a la humanidad, y el conjunto de formas discursivas en las que dicha realidad se ha ido entendiendo y plasmando, realidades que en consonancia con la "cosa" hablada son también relacionales e históricas. En esta ponencia quisiera reflexionar acerca de algunas de las modalidades de cómo se manifiesta la realidad de Dios en la literatura contemporánea latinoamericana. En este trabajo exploro una de esas manifestaciones de "Dios" en un una obra de un autor latinoamericano. Se trata de una lectura del cuento El Perseguidor (1964), de Julio Cortázar (1914-1984). Propongo esta lectura a nuestro intercambio y debate para sensibilizarnos juntos con las múltiples modalidades en las que esa realidad huidiza de "Dios" se deja entrever en las obras de los escritores contemporáneos. Por último, quisiera proponer algunas reflexiones que buscan hacerse cargo de las exigencias que se imponen hoy al discurso teológico que apuntan a hacer ver al Dios revelado en Jesús hoy.

\section{LA APUESTA POR EL SENTIDO. UNA APUESTA POR “DIOS”}

El profesor de literatura comparada y ensayista, George Steiner (1929), publicó en 1989 su ensayo titulado Presencias reales (3). Allí el autor busca hacerse cargo de los cuestionamientos provenientes tanto de reflexiones de la filosofía del lenguaje como de los horrores inefables de la historia del siglo XX, acerca de la capacidad del lenguaje de decir la realidad, de manera que haga sentido. De cara a esto, Steiner plantea la tesis sugerente y a la vez provocadora:

"La apuesta por el sentido del sentido, por el potencial de intuición y de respuesta cuando una voz humana se dirige a otra, cuando llegamos al cara a cara con el texto y la obra de arte o música, y en definitiva cuando nos encontramos con el otro en su condición de libertad, es una apuesta por la trascendencia. Esta apuesta [...] afirma la presencia de una realidad, de una "substanciación" (el alcance teológico de esta palabra es obvio) en el lenguaje y la forma. Esto supone un paso, más allá de lo fictivo o de lo meramente pragmático, desde el significado a la plenitud de significación. La conjetura es que "Dios" es, no porque nuestra gramática está gastada sino que esta vive y genera mundos precisamente porque hay la apuesta por Dios (4)".

Para mostrar si su apuesta por el sentido del sentido, y en último término, por la realidad de "Dios", tiene efectivamente un fondo verdadero, Steiner examina

(3) George Steiner, Real Presences. Chicago: The University of Chicago Press. 1989.

(4) George Steiner, Real Presences. Chicago: The University of Chicago Press. 1989, p. 4. 
múltiples expresiones de las artes -pintura, música, literatura- en diálogo permanente y crítico con las filosofías del lenguaje de Wittgenstein (5) y de Derrida. Él subraya especialmente la capacidad que poseen las obras de arte, por su constitución misma, de establecer un diálogo con el receptor y de conducir a este último a esa realidad que lo envuelve y que lo trasciende:

"Yo creo que poesía, arte y música es los que nos vincula directamente a lo que en el ser no es nuestro. Es la contra-creación y el contra-amor, tal como estos son encarnados en la estética y en nuestra percepción de significado en formas, lo que nos pone en un sano contacto con lo que trasciende, con asuntos insospechados en nuestra materialidad. Las artes se encuentran maravillosamente enraizadas en la substancia, en el cuerpo humano, en la piedra, en el pigmento, en la vibración de la cuerda o en el peso del aire en la boquilla. Todo arte y literatura notables empiezan en la inmanencia, pero no se detiene allí. Es decir, claramente, que es el empeño y el privilegio de la estética movernos hacia la presencia luminosa, hacia ese continuo entre temporalidad y eternidad, entre materia y espíritu, entre el hombre y "el otro". [...] La pregunta: “Qué es la poesía, la música, el arte?”, “Cómo ellos pueden no ser?”, “CCómo ellos actúan en nosotros y cómo podemos interpretar su acción?” son, en último término, preguntas teológicas (6)".

En su ensayo, Steiner evidencia la dinámica dialogal que primero contiene en sí misma la obra de arte, entre materia y espíritu, entre inmanencia y alteridad, y que luego se desencadena en el receptor mismo. Sin embargo, lo que en un principio es lo más sugerente y provocador, su apuesta por el sentido del sentido como una apuesta por "Dios", se vuelve cada vez más problemático. En efecto, el lector permanece desconcertado por una indeterminación respecto al objeto de su apuesta. Lo que garantiza en último término la apuesta por el sentido del sentido, pareciera ser un postulado formal más que una realidad. Dicho postulado es designado de múltiples maneras: "lo otro" o "el otro", "la trascendencia", "la presencia de una realidad”, "una presencia luminosa”. Más revelador aún de esta indeterminación inasible de aquello que funda el sentido del sentido es el hecho de que Steiner se refiera alternadamente a "Dios" entre comillas -como una conjetura o un principio formaly Dios sin comillas como una realidad cognoscible o al menos postulable. Pero en ambos casos el lector no sabe cuál es la realidad real o el contenido que encierra

(5) Algunas de las categorías empleadas por la filosofía y también por la teología como absoluto, mundo, sujeto, corresponden en la filosofía de Wittgenstein a categorías que desde el punto de vista del lenguaje designan sus límites que en su estatuto liminar permiten ver la relatividad y finitud de nuestras afirmaciones y de nuestra pertenencia al mundo. Para proseguir este diálogo crítico desde la teología con algunos de los postulados de la filosofía del lenguaje de Wittegenstein me remito al sugerente y estimulante artículo de Sergio Silva, "Lo absoluto y lo relativo. Aproximación hermenéutica. "Teología y Vida” 49, 2008, 203-220.

(6) George Steiner, Real Presences. Chicago: The University of Chicago Press. 1989, p. 227.

(7) En una entrevista con Ramin Jahanbegloo, este pregunta Steiner, a propósito de Presencias reales, acerca de su concepción de Dios. Steiner responde: "No, me niego a discutir sobre esto con usted. Es tarea suya el descubrirla en mi obra". George Steiner, Entretiens. Paris: Ed. Du Félin, ("Bibliothèque 10/18", 3175), 1990, p. 93. 
dicha referencia (7). Si bien Steiner no explicita su comprensión de esa realidad última que fundaría el sentido del sentido, y que restablecería puentes nuevos entre el lenguaje y la realidad, no creo que ello sea simplemente una evasión o un olvido. Steiner es un conocedor lúcido de la filosofía y teología contemporáneas europeas - marcadas por los debates de la condición de posibilidad de un sentido del lenguaje y del pensar después de Auschwitz- y, al mismo tiempo, un lector perspicaz de la literatura clásica y contemporánea. Su indeterminación ante la realidad de Dios, y ante lo que esta palabra designa como tal, nos habla de un problema real. La historia contemporánea y también la de nuestro continente, leída desde su reverso oscuro, desde los horrores retirados, desde sus amenazas crecientes y sobre todo, desde aquellos que son sus víctimas, han hecho pudorosa a la reflexión filosófica y teológica sobre los modos de designar a Dios y su acción en la historia. Por su parte, los escritores, enraizados en esta historia y desafiados por lo que ella plantea a la posibilidad misma de "hacer sentido", se muestran particularmente reticentes y críticos ante lo que ellos conocen y reciben de la realidad llamada "Dios". El problema que surge entonces para todo lector -crítico literario y sobre todo teólogo- que se aproxime a la literatura contemporánea en búsqueda de las diferentes figuras de Dios presentes en ella, es el de discernir adecuadamente lo que significan las comillas con las que se encierra el nombre de "Dios". Se trata de poder percibir esa realidad particular, latente o patente, que los literatos en sus obras designan, o callan, con el nombre de "Dios". En otras palabras, el trabajo es discernir en el mundo propio de una obra y en lo que este despierta en el mundo del lector, lo que sería el "Dios" de los escritores, su visión acerca de lo que ellos designan como "Dios", sus caminos de acceso o de ocultamiento.

Provocados así por la lectura de Steiner y la problemática que él aborda y que deja abierta, queremos ahora explorar la obra El Perseguidor (1964) de un autor, Julio Cortázar (1914-1984), preguntándonos por la figura de "Dios" que hay en ella e indisociablemente unido a ello, los modalidades en las que dicha realidad es dada a conocer.

\section{EL “DIOS” DEL ENTREPUERTAS QUE SE OCULTA EN EL PERSEGUIDOR}

La novela El Perseguidor es el relato de la búsqueda del jazzista Johnny Carter. Para la creación de este personaje, Cortázar se inspira de la vida y obra del saxofonista norteamericano Charlie Parker (1920-1955) a cuya memoria dedica el libro. En la novela, Johnny es ya famoso en el medio musical norteamericano de los años 50: su virtuosidad en la ejecución del saxofón alto, su sentido de la improvisación, es aplaudida en todas partes. Tiene todo para ser un hombre exitoso. Sin embargo su radical incapacidad de administrar su vida, su grupo de cercanos que, al mismo tiempo de que lo adulan, parasita de su fama, las drogas y el alcohol, todo ello hace que su vida esté marcada por la precariedad y la pobreza. Pero a Johnny, en verdad, no le interesa el éxito, ni su seguridad. Hay otra cosa que lo mueve más profundamente. Es lo que, por otra parte, intuye un crítico de jazz, Bruno, que está estableciendo una biografía de Johnny. Las largas entrevistas que él sostiene con Johnny le permiten asomarse a su verdadero talante artístico. Más allá de los que las 
apariencias muestran de Johnny y lo encerrarían en el cliché de músico maldito, de una víctima, de un perseguido por la sociedad. Johnny es más bien un perseguidor, un cazador, que está a la siga de algo en su música pero que el mismo Bruno no logra aprehender del todo. Escuchando una pieza magistral de Johnny, titulada Amorous (enamorado apasionado), Bruno atisba que hay en él un deseo de algo que lo desborda por todos lados, que lo sobrepasa, que está más allá de sus capacidades y a lo que logra aproximarse solo en algunos instantes de su música:

"Johnny persigue en vez de ser perseguido, que todo lo que está ocurriendo en la vida son azares del cazador y no del animal acosado. Nadie puede saber qué es lo que persigue Johnny, pero es así, está ahí, en Amourous, en la marihuana, en sus absurdos discursos sobre tanta cosa, en las recaídas, en el librito de Dylan Thomas, en todo lo pobre diablo que es Johnny y que lo agranda, y lo convierte en un absurdo viviente, en un cazador sin brazos y sin piernas, en una liebre que corre tras un tigre que duerme (8)".

En sus atisbos, Bruno subraya la desproporción que existe entre lo que Johnny desea y busca en su música y lo que Johnny de hecho encuentra. Lo que Johnny desea y busca está por sobre sus posibilidades. Cada vez que se acerca a ello se le aleja y solo queda en él un deseo más fuerte, de ir todavía más allá:

"Veo ahí la alta paradoja de su estilo, de su agresiva eficacia. Incapaz de satisfacerse, vale como un acicate continuo, una construcción infinita cuyo placer no está en el remate sino en la reiteración exploradora, en el empleo de sus facultades que dejan atrás lo prontamente humano sin perder humanidad. Y cuando Johnny se pierde como en esta noche en la creación continua de su música, sé muy bien que no está escapando de nada. Ir a un encuentro no puede ser nunca escapar, aunque releguemos cada vez el lugar de la cita (9)".

Más adelante es el mismo Johnny que intenta aprehender lo que él mismo ha estado acechando en su música. Él busca salir de este tiempo cronológico que avanza inexorablemente, cuyas huellas se perciben en la finitud y degradación que afecta a todas las cosas, a todo hecho humano, incluso a toda creación artística. La percepción de esta ley del tiempo se agudiza en él tras la muerte de su hija Bee. Este hecho ha catapultado aún más lejos el deseo de Johnny, al punto que él mismo termina no sabiendo exactamente qué es lo que busca y hasta dónde este deseo lo puede arrastrar. Lo buscado se vuelve huidizo y hace navegar a Johnny en un océano cuya vastedad se redobla interiormente con una conciencia de no saber que acompaña a su objeto buscado. Esta conciencia se expresa formalmente en el texto en el uso de los puntos suspensivos:

"No es cuestión de más música o de menos música, es otra cosa..., por ejemplo, es la diferencia entre que Bee haya muerto, y que esté viva. Lo que

(8) Julio Cortázar, "El perseguidor", Las armas secretas. Buenos Aires: Alfaguara, 2005, p. 124.

(9) Julio Cortázar, "El perseguidor", Las armas secretas. Buenos Aires: Alfaguara, 2005, pp. 111-112. 
yo toco es Bee muerta, sabes, mientras que lo que yo quiero, lo que yo quiero... (10)"

Johnny va a radicalizar el objeto de su búsqueda, contraponiéndolo a lo que Bruno en su biografía se atreve a tematizar al respecto, es decir, a las raíces de su música, al supuesto origen de su talento, a las implicaciones eróticas, metafísicas y hasta religiosas de su música. Johnny, por su parte, no se reconoce en ninguno de estos intentos explicativos que buscan delimitar el objeto de su deseo. Todo eso es para Johnny verdades convencionales que confortan, disfrazan y apaciguan la intensidad y el apasionamiento de lo que busca Johnny. Todo eso Johnny lo engloba en lo que gente como Bruno llaman convencionalmente "Dios":

"Está lo que tú y los que son como mi compañero Bruno llaman Dios. El tubo de dentífrico por la mañana, a eso le llaman Dios. El tacho de basura, a eso le llaman Dios. El miedo a reventar, a eso le llaman Dios. Y has tenido la desvergüenza de mezclarme con esa porquería, has escrito que mi infancia y mi familia, y no sé qué herencias ancestrales... Un montón de huevos podridos y tú cacareando en el medio, muy contento con tu Dios. No quiero tu Dios, no ha sido nunca el mío (11)".

La discrepancia mayor que tiene el creador Johnny con su crítico y biógrafo Bruno tiene que ver con las explicaciones que este intenta dar de lo que para el mismo Johnny permanece oscuro y no por eso menos perseguido y que gente como Bruno designa detrás de la palabra "Dios". "Dios" para Johnny no es una realidad como si fuera un objeto más entre objetos de este mundo que están banalmente ahí, como el tubo de pasta de dientes. Tampoco es un lugar de desechos a donde van a parar nuestras claudicaciones y nuestras miserias que permanecen sin explicación y cuya responsabilidad las endosaríamos a un ser trascendente que llamamos "Dios". Y tampoco es una realidad que funcionaría como un analgésico o un tranquilizante que nos dispensaría de la pregunta acerca del sentido de nuestra vida de cara a la muerte, atenuando con ello nuestros miedos no solo ante el cuándo vamos a morir sino también y sobre todo ante el cómo moriremos.

Johnny no acepta estas explicaciones porque el objeto de su deseo, lo que él busca solo lo puede decir a través de su música. Para él, el lenguaje de la ejecución de su saxo es el menos inadecuado para decir el móvil de su búsqueda, más allá de toda explicación reductora que pretendería encerrarlos en alguna verdad habitual: "Yo no sé si hay Dios, yo toco mi música, yo hago mi Dios (12)". Johnny no acepta tampoco estas explicaciones porque funcionan como remedos de su deseo, o en lenguaje de Johnny no son sino "trampas de ratones": "Trampas para que uno se conforme, sabes, para que uno diga que todo está bien. Bruno, yo creo que Lan y el jazz, sí, hasta el jazz, eran como anuncios en una revista, cosas

(10) Julio Cortázar, "El perseguidor", Las armas secretas. Buenos Aires: Alfaguara, 2005, p. 143.

(11) Julio Cortázar, "El perseguidor", Las armas secretas. Buenos Aires: Alfaguara, 2005, p. 142.

(12) Julio Cortázar, "El perseguidor", Las armas secretas. Buenos Aires: Alfaguara, 2005, p. 142. 
bonitas para que me quedara conforme como te quedas tú porque tienes Paris y tu mujer y tu trabajo... (13)"

En el fondo, él no acepta esas explicaciones, pues de alguna manera él ha ya intuido en su música algo de lo que está buscando, más allá de este tiempo intramundano vivido bajo el signo de la fugacidad y de la finitud, algo que tiene en el aquí y ahora, sabor de "para siempre". Johnny describe en imágenes y mediante comparaciones y no en conceptos lo que él entrevió y pregustó una noche en 1951, tocando en Nueva York, junto a Miles y Hal:

"Miles tocó algo tan hermoso que casi me tira de la silla, y entonces me largué, cerré los ojos, volaba. Bruno, te juro que volaba... Me oía como si desde un sitio lejanísimo pero dentro de mí mismo, al lado de mí mismo, alguien estuviera de pie... No exactamente alguien... No era alguien, uno busca comparaciones... Era la seguridad, el encuentro, como en algunos sueños. ¿No te parece?, cuando todo está resuelto, Lan y las chicas te esperan con un pavo al horno, en el auto no atrapas ninguna luz roja, todo va dulce como una bola de billar. Y lo que había a mi lado era como yo mismo pero sin ocupar ningún sitio, sin estar en Nueva York, y sobre todo sin tiempo, sin que después... sin que hubiera después... Por un instante no hubo más que siempre... (14)”.

En su último diálogo con Bruno, Johnny se atreve a confesarle cuál es el "Dios" que él está buscando, y que, de alguna manera, atisbó esa noche en Nueva York y que ahora permanece como lo deseado ardientemente pero que se muestra indisponible a su deseo:

"Sobre todo no acepto a tu Dios - murmura Johnny-. No me vengas con eso, no lo permito. Y si realmente está del otro lado de la puerta, maldito si me importa. No tiene ningún mérito pasar del otro lado porque él te abra la puerta. Desfondarla a patadas, eso sí. Romperla a puñetazos, eyacular contra la puerta, mear un día entero contra la puerta. Aquella vez en Nueva York yo creo que abrí la puerta con mi música, hasta que tuve que parar y entonces el maldito me la cerró en la cara nada más que porque no le he rezado nunca, porque no quiero saber nada con ese portero de librea, ese abridor de puertas a cambio de una propina, ese... (15)"

De esta aproximación de lo que Johnny Carter persigue en su búsqueda, de su imagen de "Dios" entre comillas, se desprende, en primer lugar, una visión de la existencia del hombre como un buscador, un cazador, cuya presa está más allá de las capacidades de su deseo y que, en lenguaje de Bruno, hacen de Johnny un "absurdo viviente", "un cazador sin brazos ni piernas, una liebre que se lanza a la caza de un tigre". Néstor García Canclini en su ensayo sobre Cortázar, describe así la visión del hombre encarnada en Johnny, radicalmente buscador, un inconformista e insatisfe-

(13) Julio Cortázar, "El perseguidor", Las armas secretas. Buenos Aires: Alfaguara, 2005, p. 145.

(14) Julio Cortázar, "El perseguidor", Las armas secretas. Buenos Aires: Alfaguara, 2005, p. 145.

(15) Julio Cortázar, "El perseguidor", Las armas secretas. Buenos Aires: Alfaguara, 2005, p. 146. 
cho con lo que se le ofrece bajo el ropaje de lo usual, de lo habitual o del "así ha sido siempre".

"El hombre es para Cortázar una avidez obstinada, un enigma que nunca se resuelve plenamente, la persecución de un horizonte que huye [...] Quien se liga a esta aventura sabe que, aunque sea imposible acceder a un sentido absoluto, por lo menos hay más sentido en vivir del otro lado de la costumbre. La única justificación de la existencia está en el no instalarse en ninguna justificación, no acomodarse para siempre en ninguna de las salas del laberinto, sino ir una y otra vez al encuentro de la nueva realidad. "Abrir de par en par las ventanas y tirar todo a la calle, pero sobre todo hay que tirar también la ventana y nosotros con ella (Cortázar)' (16)".

Concomitante con lo anterior, de este mismo personaje Johnny se desprende una visión de su "Dios". En efecto el "Dios" que está buscando Johnny, no es una realidad que funciona como un calmante del deseo del hombre ni como una verdad convencional ni como analgésico del miedo reprimido y soterrado al cómo moriremos que se esconde tras la palabra "Dios". Tampoco es como un portero de librea que estaría pronto a los que lo buscan para abrirles la puerta. Todo ello es insatisfactorio para Johnny pues permanece aquende su deseo. Lo que Johnny está buscando es una realidad más allá de lo que el lenguaje expresa y encierra en la palabra "Dios. Para Johnny esta palabra es un vector, una flecha que se orienta hacia lo que él con su música puede atisbar, pregustar dejando un sabor para siempre, es el encuentro, la seguridad y que no tiene otro límite que la infinitud del deseo del hombre. En otros términos, el "Dios" de Johnny y que estaría del otro lado de la puerta que él entreabrió con su música, apunta a esa realidad que Emmanuel Levinas insta a expresar "autrement qu'être", "de otra modo que ser (17)".

Sin embargo, lo que hace que la existencia del buscador infatigable que es Johnny quede marcada por un sino trágico es, por un lado, el hecho de que no articula la tensión que existe y permanece siempre entre lo relativo parcial y fragmentario y lo que se atisba como definitivo. Una vez entreabierta la puerta con su música y entrevisto lo que tenía un carácter definitivo y para siempre, la recaída de Johnny al aquí y ahora le resulta aún más insufrible, por la "insoportable levedad del ser" que todo lo tiñe. Su deseo queda aferrado a lo que aprehendió aquella noche en Nueva York y que estaba detrás de la puerta. Al lado de eso, las mediaciones concretas y pasajeras que le hicieron posible acercarse a lo que había del otro lado de la puerta: el vestido rojo de Lan, su hija Bee, incluso su música, le parecen nada (18). Al desvalorar lo relativo y finito como la mediación necesaria para abrirse, desde ella y a través de ella, a lo que tenga fuerza y realidad de definitivo, el deseo de Johnny se ve condenado a la imposibilidad de abrirse de nuevo a esa realidad atisbada. En el fondo, Johnny no obedece y no acepta obedecer a la ley de su propia finitud, al interior de la cual, él pregustó lo que hablaba de otra dimensión, de otro tiempo, de lo que tiene sabor a "para siempre".

(16) Néstor García Canclini, Cortázar, una antropología poética. Buenos Aires: Nova, 1968, p. 110.

(17) Emmanuel Levinas, Autrement qu'être ou au-delà de l'essence. La Haye : Martinus Nijhoff, 1978[Traducción española de Antonio Pintor Ramos. De otro modo que ser. Salamanca: Sígueme, $1987]$.

(18) Cf. Julio Cortázar, "El perseguidor”, Las armas secretas. Buenos Aires: Alfaguara, 2005, p. 143. 
Por otro lado, este sino trágico de Johnny proviene también del hecho de que aquello que Johnny está buscando, precisamente porque lo ha ya pregustado, permanece indisponible a su deseo. Johnny no acepta que lo que busca no es la mera proyección de la infinitud de su deseo sino que es fruto de un encuentro con un otro libre que está más allá del propio deseo, por tenaz y agónico que este sea. Ya en un plano interpersonal, ese otro no puede ser recibido en su alteridad libre sino aceptando que venga desde sí mismo y se done. El carácter trágico de Johnny resulta de no consentir al hecho de que si su deseo de absoluto pervive y lo incita a ir más allá de las costumbres es porque algo ya le ha sido dado, a través de mediaciones concretas del aquí y ahora: personas que han confiado honestamente en su talento, su propia capacidad musical, la conciencia de su propio límite y, sobre todo, el hecho de que su deseo, quiéralo o no, es llevado y sostenido por el deseo de los otros. De alguna manera, el mismo Johnny, en un momento de lucidez, percibe cómo él mismo se pone en una situación tal que lo que más busca no lo podrá reencontrar:

_"Me parece que he querido nadar sin agua -murmura Johnny-. Me parece que he querido tener el vestido rojo de Lan pero sin Lan. Y Bee está muerta, Bruno (19)".

\section{EL DIOS DE LA INICIATIVA IMPREVISIBLE QUE SE DESOCULTA}

Johnny representa el paradigma de la existencia humana entendida como búsqueda agónica de un absoluto que dé sentido al tiempo marcado por su carácter efímero, por el cuño de la muerte. Además él está tras un absoluto que, al mismo tiempo que se deja vislumbrar, está más allá de lo habitual y convencional, de lo que incluso se designa en el lenguaje tras la palabra "Dios" entre comillas. Johnny aparece como un cazador del absoluto, movido por su deseo insaciable y guiado por sus visiones enigmáticas. La centralidad de la pregunta acerca de "Dios", de los modos según los cuales se manifiesta como algo deseable, se ve reforzada por las afinidades que hay este cuento con el libro del Apocalipsis de Juan.

El Perseguidor presenta signos intertextuales que establecen un vaivén entre la estructura de esta novela y el libro del Apocalipsis. Uno de sus epigramas nos advierte de este hecho: "Sé fiel hasta la muerte" (Apocalipsis 2, 10). El sentido de esta frase se ofrece como una clave de lectura del conjunto de la obra: Johnny está en busca de una revelación de algo, de alguien que entrevió una noche y que desde entonces se enquistó en él como una obsesión febril que no lo abandonó más. Al mismo tiempo, esta frase da una dimensión parabólica al conjunto del itinerario recorrido por Johnny: Es un "vidente" desesperado por una revelación, por un Apocalipsis que está cerrado, y lo buscado, indisponible a su voluntad de búsqueda.

A su vez, desde esta obra, la frase del Apocalipsis cobra nuevas dimensiones. Es una cita tomada de una de las cartas que el Resucitado dicta al vidente Juan, dirigida a la iglesia de Esmirna. Esta comunidad se ve confrontada a una crisis de identidad, de cara a la comunidad judía tras la destrucción del Templo de Jerusalén

(19) Julio Cortázar, "El perseguidor", Las armas secretas. Buenos Aires: Alfaguara, 2005, p. 145. 
(70 d. C). En efecto, al no haber Templo ni sacerdocio asociado a él, la cuestión de los símbolos que definen la identidad de la comunidad judía se ha vuelto crucial. A ello se agrega que muchos judíos han debido dejar la tierra de Israel. De estos mismos judíos en la diáspora provienen muchos de los neocristianos que han abrazado el mensaje de Jesús. Estos últimos son despreciados por sus hermanos de pueblo, al considerarlos una secta heterodoxa al interior del judaísmo. Los cristianos se ven así cuestionados no solo en su identidad sino también en su fe en el Señorío del Resucitado: ¿Dónde está? ¿Cómo actúa en la historia de la que se muestra ausente? En este presente, el Resucitado es el que toma la iniciativa de desocultarse, de autocomunicarse. Su manifestación desborda por todos lados los cuestionamientos y las búsquedas que inquietaban a las comunidades cristianas nacientes. Por su parte, el vidente Juan padece en carne propia los sufrimientos padecidos por sus hermanos a causa de la fe en Jesús Resucitado. Y él colabora con la iniciativa imprevisible del Resucitado haciéndose disponible a ella: "El día del Señor quedé en el Espíritu y oí detrás de mí una fuerte voz, como un toque de trompeta" (Ap 1, 10). Y el objeto de la visión es algo que se puede decir solo en una imagen, cuyos distintos símbolos convergen hacia el poderío del Señor Resucitado y apuntan a suscitar, en el vidente y en los que reciban esta imagen, un sentimiento de sobrecogimiento reverencial:

"Me volví a ver de quién era la voz que me hablaba, y la hacerlo vi siete candelabros de oro y en medio de los siete candelabros vi a alguien que parecía ser un hijo de hombre, vestido con una ropa que le llegaba hasta los pies, y con un cinturón de oro a la altura del pecho. Sus cabellos eran blancos como la lana o como la nieve, y sus ojos parecían llamas de fuego. Sus pies brillaban como bronce pulido, fundido en un horno; y su voz era tan fuerte como el ruido de una cascada. En su mano derecha tenía siete estrellas y de su boca salía una espada de dos filos. Su cara era como el sol cuando brilla en todo su esplendor". (Ap 1.12-16)

Él se presenta como Señor y juez de la historia, el murió y ahora vive, el primero y el último. Esta manifestación del señorío de Jesús, puesta por escrito por el vidente, es la revelación de lo que el Señor ya es para siempre, en el aquí y ahora amenazante, allí mismo en donde su presencia se había oscurecido para los creyentes.

Ahora bien esta autocomunicación del Resucitado no busca atenuar o minimizar las exigencias críticas del tiempo presente, ni mucho menos dispensar a los cristianos de esta comunidad del testimonio que están llamados a dar del Señor que ahora vive. Al contrario, esta visión apunta a que sus destinatarios lean y vivan su presente a la luz del acontecimiento definitivo de Jesús Resucitado. "No tengas miedo de lo que vas a sufrir..."(Ap. 2,9) Desde allí entonces los discípulos de Jesús son llamados a empeñar sus vidas con un sentido nuevo en la lucha que deben librar en nombre de su fe. El mismo Resucitado que así se ha manifestado es el que sostiene, acompaña y recompensa a los que se mantienen fieles, incluso hasta la muerte. Esta visión es entonces una palabra de aliento y de esperanza que incita a sus destinatarios a no restarse del combate que han de librar por su fe. Al mismo tiempo, los abre a auscultar más hondamente en ese mismo presente lo que el 
Espíritu del Resucitado sigue diciendo a su Iglesia. El presente, en su aspectos dramáticos y conflictivos, cobra así una nueva dimensión, no solo como el lugar y el tiempo del auténtico testimonio, sino también el lugar y el tiempo para abrirse al obrar discreto del Espíritu del que ahora vive Resucitado.

\section{A MODO DE CONCLUSIÓN}

Si retomamos la imagen del "Dios" de Johnny, esta es el resultado de lo que él, a través de su música y movido por su deseo, busca incansablemente y logra conquistar. Su búsqueda describe originalmente un movimiento ascendente y agónico, como lo indica su apellido "Carter" "carretonero", una figura contemporánea de Sísifo, arrastrando cuesta arriba con su búsqueda, amenazada por la incertidumbre y el sinsentido que pesan sobre sus hombros. Un "Dios" que, al mismo tiempo que él lo busca y entrevé, se aleja cada vez más, produciéndose así una distancia insalvable entre la voluntad de búsqueda y un "Dios" cuya puerta no abrió más. Como escribe Bruno respecto a lo que Johnny persigue: "Ir a un encuentro no puede ser nunca escapar, aunque releguemos cada vez el lugar de la cita (20)".

El Dios del vidente Juan es que el que ve y conoce los riesgos y penurias que viven los que lo confiesan y toca y fortalece a los que sienten desfallecer sus fuerzas. Ahora su venida no está condicionada por la situación crítica que viven los creyentes ni subordinada a la urgencia con que estos invocan su presencia. Si bien estos aspectos están presentes, la condición creyente en el Resucitado es definida por una apertura a su venida libre y soberana, en el tiempo y según las modalidades que Él mismo determine. Esta apertura se traduce en una esperanza: así como el Resucitado ya se manifestó libremente a través del vidente, así también el deseo creyente, guiado por la esperanza, ausculta su acción discreta y poderosa en el presente.

El "Dios" entrevisto por Johnny hace que la vida del aquí y ahora se vuelva aun más insoportable por su contingencia y precariedad. Y su deseo de algo definitivo así reavivado hace de él un hombre radicalmente inconforme y rebelde, ante lo que se le ofrece parcial y fragmentariamente en este tiempo fugaz. Al mismo tiempo, crece en él el sentimiento de ser incomprendido por los demás, lo que termina aislándolo de las búsquedas y de los deseos de los otros. El Dios del vidente Juan incita a este y a sus compañeros de aflicción a vivir, desde una nueva hondura, el tiempo presente. Es allí donde el Espíritu sigue hablando a las Iglesias y sosteniendo los empeños de los que por Él viven y mueren. Estos no se repliegan en sí mismos sino que reavivan su deseo de que el Señor vuelva. A ello contribuye la poética visual en la que se expresa el desvelamiento del Resucitado, de lo definitivo en el aquí y ahora crítico de la historia. Es esta historia, leída desde la fe que deviene así el espacio privilegiado y no el obstáculo en donde los creyentes se abren a la acción del Señorío del Resucitado. El desvelamiento del Señor acontece en el discernimien-

(20) Julio Cortázar, "El perseguidor", Las armas secretas. Buenos Aires: Alfaguara, 2005, pp. 111112 . 
to continuo que los creyentes realizan de cara su propia historia. Al mismo tiempo, ese discernimiento ha de permanecer radicalmente abierto al Señor que es más grande que la historia en la que se manifiesta y oculta y más fuerte que el deseo de aquellos que lo invocan. En último término, esta apertura al Dios "semper maior" define un modo de estar en el mundo de los creyentes, caracterizado por un deseo común que lo viven bajo el régimen de la esperanza y que no tiene otro objeto que la venida del Señor: "El Espíritu Santo y la esposa del Cordero dicen: “¡Ven!” y el que escuche dice: “¡Ven!”. Amén. ¡Ven, Señor Jesús! (Ap 22, 16.20).

El "Dios" entrevisto por Johnny tiene una función crítica respecto a las formas discursivas sobre Dios. En efecto, él nos advierte de los límites y de los riesgos que acompañan a la designación de Dios en el lenguaje y, con ello, en la historia. "Dios" para él es lo que está más allá de las costumbres, de lo habitual, de nuestros miedos $\mathrm{y}$, sobre todo, de la tarea por el sentido de cara a la finitud y a la muerte. Por su parte, las imágenes que expresan al Resucitado tienen por objeto que los creyentes rompan por decir así su comprensión habitual de Él y se abran a una nueva experiencia allí donde su deseo lo percibe ausente y distante de los suyos, y donde los hechos tenaces de la historia desmienten su presencia y actuar.

En ambos casos hay un fuerte potencial crítico respecto a las formas de designación de Dios, tanto en filosofía como en teología. Un Dios que una vez conceptualizado corre el riego de convertirlo en una realidad disponible y por qué no decirlo, manipulable, desperfilando su carácter trascendente y vivo y atenuando así su inextirpable compromiso con la historia concreta y muchas veces dramática de los hombres.

No se trata de que la teología renuncie al "esfuerzo del concepto" (Hegel) sino que dicho esfuerzo ha de articularse más vivamente con el "Dios patético" de la Biblia que se encuentra implicado en la historia de su pueblo, que busca infatigablemente al hombre (21). Tampoco se trata de una teología que se vuelva muda sino que en sus modos de designar a Dios y su acción en el presente, asuma más decididamente sus dimensiones relacional, histórica y apofática. Johnny a través del pudor con el que osa designar lo que vislumbra como su objeto: (Algo, Alguien), abierto a un "plus" que, en último término, solo puede ser dicho en su realidad elusiva mediante puntos suspensivos a los que Johnny se aferra en su búsqueda tan infatigable como desesperada. Juan, por su parte, expresa en un conjunto de imágenes el carácter desbordante de Dios, más allá de todo deseo, por ilimitado que sea, y más allá de todo presente, por crítico y amenazante que se imponga. En su reflexión creyente acerca de Dios, la teología ha desplegar un esfuerzo de imaginación heurística para elaborar formas discursivas que hablen de este exceso de Dios y de su actuar, y a la vez, sean elocuentes para el exceso - de otra magnitud- de la opacidad de la historia. Ahora bien, para decir el exceso relacional de Dios hacia el hombre, la teología necesita hacerse ella misma buscadora del Dios vivo y volver una y otra vez conjunto de las formas discursivas en las que se expresa, de manera originaria, la confesión de la fe, contenida en las Escrituras. En efecto, el conjunto de las formas, sean ellas narrativas, poéticas, parabólicas, parenéticas, prescriptivas, sapienciales, proféticos

(21) Paul Ricoeur, "Philosophie et prophetisme II”, Lectures 3. Paris: Seuil, 1994, pp. 180.184. 
o apocalípticos, describe los rasgos del talante y actuar de ese Dios que se revela ocultándose y se oculta revelándose, que está más allá del lenguaje y de toda representación: "El nombre de Dios es a la vez lo que circula entre los géneros y las escrituras, no perteneciendo a ninguno pero intersignificado por todos, y también lo que escapa a cada uno y a todos, en signo de incompletud de todos los discursos sobre Dios. Este es nombrado alternativamente como el punto de mirada común y como el punto de fuga exterior a cada discurso y a su conjunto (22)". Al mismo tiempo, cada una de estas formas propone al hombre caminos para que este lo pueda buscar, encontrar y confesar. Una teología que no tema expresar sus propios tanteos, balbuceos y desconciertos por los cuales ella también busca en las rutas del tiempo abrirse a la iniciativa imprevisible de Dios.

\title{
RESUMEN
}

En este artículos nos proponemos acercarnos al modo como algunos escritores latinoamericanos se refieren a Dios. Se trata de un acercamiento secular y que se inscribe al interior de un trabajo eminentemente literario. Asumiendo esta óptica, ofrecemos una recepción teológica de este modo literario de referirse a Dios, poniéndola en diálogo con la realidad del Dios de Jesús y los modos narrativos y sistemáticos en que se ha dicho y se continúa diciendo y actualizando su novedad.

Palabras clave: Dios, literatura, teología, evangelización.

\begin{abstract}
In this article, the author proposes that we examine the way in which some Latin American writers refer to God. We are dealing with a secular approach, and one that is found within an eminently literary task. Adopting this focus, the author offers a theological reception of this literary mode of referring to God, placing it within a dialogue with the reality of the God of Jesus, and the narrative and systematic modes in which its novelty has been expressed and continues to be expressed and actualized.
\end{abstract}

Key words: God, literature, theology, evangelization.

(22) Paul Ricoeur, "Expérience et langage dans le discours religieux". En Michel Henry, Paul Ricoeur, Jean-Luc Marion, Jean-Louis Chrétien, Phénoménologie et Théologie, Paris : Criterion, 1992, pp. 35-36. Sobre una idea de la autocomunicación de Dios atestada en la Biblia y expresada en su exceso gracias la pluralidad de géneros literarios así como de las consecuencias que se imponen a la teología hoy. Cf. Paul Ricoeur, "Herméneutique de l’idée de la Révélation" en Paul Ricoeur, Emmanuel Levinas, Edgar Haulotte, Etienne Cornélis y Claude Geffré, La Révélation. Bruxelles : Publications des Facultés universitaires Saint-Louis, (“Théologie ”, 7), 1984, pp. 15-54. 
